Krzysztof Sala

Uniwersytet Pedagogiczny im. Komisji Edukacji Narodowej w Krakowie

\title{
Polityka społeczna wobec osób niepełnosprawnych w Polsce
}

DOI: $10.19195 / 1643-0328.21 .6$

Słowa kluczowe: polityka społeczna, niepełnosprawność, osoba niepełnosprawna, aktywność zawodowa

\section{Wprowadzenie}

Problem niepełnosprawności stanowi istotny element polityki społecznej i gospodarczej państwa. Sytuacja społeczna i ekonomiczna osób niepełnosprawnych jest kwestią często podejmowaną $\mathrm{w}$ debatach politycznych w Polsce i na świecie. Zajmuje ona także istotne miejsce $\mathrm{w}$ tematyce poruszanej przez media. W Polsce niepełnosprawność dotyczy co dziesiątej osoby i jest obecna w co czwartym gospodarstwie domowym. W szerokim zakresie podejmowane są działania zmierzające do równouprawnienia i poprawy sytuacji osób niepełnosprawnych przez likwidację barier architektonicznych, prawnych czy też mentalnych.

Pojęcie niepełnosprawności zajmuje również ważne miejsce jako przedmiot badań polityki społecznej, ekonomii, socjologii, filozofii oraz psychologii.

Celem artykułu jest przedstawienie wybranych elementów polityki społecznej wobec osób niepełnosprawnych w Polsce przez wskazanie zadań funduszu celowego odpowiedzialnego za ten obszar (PFRON) oraz zadań samorządów w tym zakresie.

Publikacja powstała na podstawie ogólnodostępnych danych statystycznych Głównego Urzędu Statystycznego, a także literatury i źródeł internetowych. Metodą badawczą, jaką zastosowano w artykule, była analiza wtórna dostępnych dokumentów odnoszących się do wybranych aspektów sytuacji społecznej i ekonomicznej osób niepełnosprawnych oraz polityki społecznej wobec tych osób.

Podejście badawcze uwzględniało dane ilościowe i jakościowe dotyczące polityki społecznej i jej wpływu na sytuacje osób niepełnosprawnych.

Literatura zagraniczna związana z przedmiotem jest obszerna, natomiast krajowa stosunkowo uboga. Uzasadnienie wyboru tematu wynika $\mathrm{z}$ chęci wniesienia własnego głosu do naukowej dysputy traktującej o wybranym społeczno-ekonomicznym aspekcie 
życia osób z niepełnosprawnościami w Polsce oraz konieczności zainicjowania debaty wokół polityki społecznej wobec osób niepełnosprawnych.

Teza, jaką należy postawić, opiera się na założeniu, że stosowane dotychczas mechanizmy aktywizacji zawodowej oraz politykę społeczną państwa charakteryzuje bardzo ograniczona skuteczność. Występują bariery, których realizowana obecnie polityka społeczna i system rehabilitacji zawodowej nie eliminują.

\section{Pojęcie niepełnosprawności i jego skala w Polsce}

Pojęcie niepełnosprawności nie ma jednoznacznej definicji. Jest definiowane na gruncie prawnym, medycznym oraz naukowym. Termin „niepełnosprawnośc” pochodzi z czasów starożytności ${ }^{1}$. Do XIX wieku niepełnosprawność była związana $\mathrm{z}$ inwalidztwem powstałym w czasie służby wojskowej. Po II wojnie światowej zwrócono uwagę na zdolność do wykonywania pracy jako kryterium odróżniające człowieka zdrowego od inwalidy. Jednak w definicji z tamtych czasów nie brano pod uwagę dzieci, młodzieży oraz osób starszych.

Druga połowa XX wieku to okres, w którym osoby niepełnosprawne zaczęto określać pojęciami: kaleka, upośledzony, inwalida czy też niedostosowany. Takie określenia, oprócz swojego negatywnego wydźwięku, odwołują się jedynie do niektórych schorzeń zdrowotnych.

Światowa Organizacja Zdrowia w celu uporządkowania terminologii opracowała w 1980 roku Międzynarodową Klasyfikację Uszkodzeń, Niepełnosprawności i Upośledzeń (International Classification of Impairments, Disabilities and Handicaps - ICIDH), w obrębie której zdefiniowano ${ }^{2}$ :

- niepełnosprawność funkcjonalną (disability) - oznacza wszelkie ograniczenia lub braki wynikające z uszkodzenia zdolności wykonywania czynności w sposób i w zakresie uważanym za normalny i prawidłowy dla człowieka;

- upośledzenie lub niepełnosprawność społeczną (handicap) - oznacza mniej uprzywilejowaną lub mniej korzystną sytuację danej osoby wynikającą z uszkodzenia lub niepełnosprawności funkcjonalnej, która ogranicza lub uniemożliwia jej wypełnianie ról związanych z wiekiem, płcią oraz sytuacją społeczną i kulturową.

W latach 70. XX wieku organizacje zrzeszające osoby niepełnosprawne zaczęły podkreślać niedoskonałości modelu medycznego w definiowaniu i rozumieniu niepełnosprawności z racji ograniczeń dotykających niepełnosprawnych $\mathrm{w}$ ich środowiskach i powiązań z postawami społecznymi. Model społeczny uznaje niepełnosprawność za wynik ograniczeń doświadczanych przez osoby nią dotknięte (uprzedzenia, brak dostępu do rynku pracy, utrudniony dostęp do budynków, transportu publicznego). Przyczyna nie tkwi zatem w jednostce, lecz w barierach społecznych i ekonomicznych. Model

1 P. Ulman, Sytuacja ekonomiczna osób niepełnosprawnych i ich gospodarstw domowych w Polsce, Kraków 2011, s. 21.

2 C. Barnes, G. Mercer, Niepetnosprawność, Sic!, przeł. P. Morawski, Warszawa 2008, s. 22. 
społeczny zakłada, że społeczeństwo w znacznym stopniu przyczynia się do upośledzenia ludzi niepełnosprawnych.

Według obowiązującej ustawy o rehabilitacji zawodowej i społecznej oraz zatrudnianiu osób niepełnosprawnych niepełnosprawność oznacza ,trwałą lub okresową niezdolność do wypełniania ról społecznych z powodu stałego lub długotrwałego naruszenia sprawności organizmu, w szczególności powodującą niezdolność do pracy" ${ }^{3}$. W świetle tej definicji niepełnosprawny to osoba, która nie jest w stanie w pełni spełniać swojej funkcji jako jednostka w społeczeństwie, zwłaszcza - realizować swoich zadań na gruncie zawodowym. Niesie to za sobą określone skutki dla samego niepełnosprawnego oraz dla jego rodziny.

Na przestrzeni wieków polityka społeczna wobec osób niepełnosprawnych cechowała się zmiennością. Można wyróżnić trzy zasadnicze okresy:

- wrogości,

- litości i nieuzasadnionych nadziei,

— badań szczegółowych i uzasadnionego optymizmu co do przydatności społecznej.

Okres wrogości był charakterystyczny dla czasów starożytności. Ułomność traktowano w większości przypadków jako karę za grzechy. Eliminowano słabe jednostki, aby nie były ciężarem dla państwa ${ }^{4}$. Ułomne noworodki porzucano lub zabijano. Jedynie prawo rzymskie ustanowiło funkcję kuratora-opiekuna osób starszych, chorych i niedołężnych.

Okres litości i nieuzasadnionych nadziei był związany z pojawieniem się chrześcijaństwa. Kierując się zasadą miłości bliźniego, chrześcijanie nieśli pomoc każdemu, kto jej potrzebował, także niepełnosprawnym. W Polsce o początkach opieki nad niepełnosprawnymi możemy mówić od czasów pojawienia się zakonów mniszych, tj. od XII wieku. Pierwszymi miejscami, w których niepełnosprawnym udzielano pomocy, były zakładane przez cystersów hospicja. Papież Grzegorz Wielki wspierał zakładanie przytułków i xenodochii ${ }^{5}$.

Ostatni okres - badań szczegółowych i uzasadnionego optymizmu co do przydatności społecznej - rozpoczął się w XIX wieku. Był związany z rozwojem wszelkiego rodzaju inicjatyw zajmujących się kształceniem, opieką i poprawą sytuacji bytowej osób pokrzywdzonych przez los. W tym okresie pojawiły się pierwsze zakłady opiekuńcze i edukacyjne. W 1898 roku w USA powstała pierwsza szkoła kształcąca profesjonalne kadry w zakresie socjalnym.

Dane na temat skali niepełnosprawności w Polsce publikuje m.in. GUS. W 1974 roku przeprowadzono pierwszy w Polsce mikrospis oceniający skalę zjawiska. Jego wyniki pokazywały, że w Polsce populacja osób mających orzeczenie o inwalidztwie liczyła 1374308 osób, co stanowiło 4,1\% ogółu ludności w Polsce ${ }^{6}$. Odsetek kobiet wynosił 47,4\% zbiorowości. Najwięcej osób mieszkało w miastach (70\%), a wykształcenie pod-

3 Ustawa o rehabilitacji zawodowej i społecznej oraz zatrudnianiu osób niepełnosprawnych z 27 sierpnia 1997 r. (tekst jednolity, Dz.U z 2011 r. Nr 127, poz. 721 ze zm.).

${ }^{4}$ Platon, Państwo, przeł. W. Witwicki, Kęty 1997, ks. 5, par. 9-10, s. 18.

5 J. Majka, Katolicka nauka społeczna, Warszawa 1988, s. 121.

6 B. Balcerzak-Paradowska, Sytuacja bytowa gospodarstw domowych osób niepetnosprawnych, [w:] Sytuacja osób niepetnosprawnych w Polsce, red. B. Balcerzak-Paradowska, Warszawa 2002, s. 32. 
stawowe deklarowało blisko $46 \%$ niepełnosprawnych. Dane wskazywały, że co czwarty inwalida podejmował zatrudnienie. W 1988 roku liczba inwalidów wynosiła 3735 509, co stanowiło $10 \%$ całego społeczeństwa. Wyraźny wzrost w porównaniu z rokiem 1974 wynikał z ujawnienia prawdy o stanie zdrowia ludności wiejskiej.

Według Narodowego Spisu Ludności i Mieszkań z 2002 roku liczba osób niepełnosprawnych w Polsce wyniosła 5456711 osób. Odsetek mężczyzn stanowił ponad 47\% ogółu, a niepełnosprawni mieszkańcy miast - blisko 59\%. Wzrósł poziom wykształcenia osób niepełnosprawnych do 4,6\%, w porównaniu z 3\% w 1988 roku. Biorąc pod uwagę poziom wykształcenia całej populacji w Polsce, można stwierdzić, że wykształcenie osób niepełnosprawnych jest wyraźnie niższe. Współczynnik aktywności zawodowej osób niepełnosprawnych w porównaniu z 1988 rokiem zmniejszył się z $26,4 \%$ do $19,2 \%$.

Najnowsze badania statystyczne dotyczące osób niepełnosprawnych przeprowadzono w 2004 roku. Dane wskazują na wzrost liczby niepełnosprawnych do 6206000 osób. Mężczyźni stanowili blisko $46 \%$ ogólnej liczby bezrobotnych, a prawie $60 \%$ mieszkało w mieście. Udział niepełnosprawnych z wykształceniem wyższym wzrósł do poziomu 6,3\%.

Według wyników Narodowego Spisu Powszechnego Ludności i Mieszkań z 2011 roku liczba osób niepełnosprawnych ogółem wynosiła na koniec marca 2011 roku około 4,7 mln (dokładnie 4 697,0 tys.). Tym samym liczba osób niepełnosprawnych w Polsce stanowiła 12,2\% ludności kraju wobec 14,3\% w 2002 roku (blisko 5,5 mln osób niepełnosprawnych w 2002 roku). Udział mężczyzn wśród osób niepełnosprawnych wynosił $46,1 \%$ wobec $53,9 \%$ kobiet $^{7}$.

\section{Polityka państwa wobec osób niepełnosprawnych w Polsce}

Podstawowym dokumentem, który dotyczy osób niepełnosprawnych w Polsce, jest uchwała Sejmu Rzeczypospolitej Polskiej z dnia 1 sierpnia 1997 roku - Karta praw osób niepełnosprawnych. Została ona sformułowana w oparciu o obowiązujące prawo międzynarodowe: Powszechną deklarację praw człowieka, Konwencję o prawach dziecka, Standardowe zasady wyrównywania szans osób niepełnosprawnych czy też Konstytucję RP. Na mocy jej postanowień rząd został zobligowany do urzeczywistnienia praw osób niepełnosprawnych oraz doprowadzenia do ich głębszej integracji ze społeczeństwem.

Programy pomocowe dotyczą szczebla ogólnokrajowego i lokalnego. Programy ogólnokrajowe są realizowane przez Państwowy Fundusz Rehabilitacji Osób Niepełnosprawnych. Fundusz jest także najczęściej liderem projektów realizowanych ze środków Europejskiego Funduszu Społecznego. Wśród wielu programów pomocowych można wymienić:

- program aktywizacji zawodowej absolwentów skierowany do dzieci, młodzieży „Junior",

7 http://stat.gov.pl/spisy-powszechne/nsp-2011/ (dostęp: 23.05.2016). 
— program edukacyjny wyrównujący szanse edukacyjne osób ze środowisk wiejskich „Uczeń na wsi”,

- program pomocy rodzinom z dzieckiem niepełnosprawnym „Wczesna pomoc dziecku niepełnosprawnemu",

- program „Telepraca oraz inne elastyczne formy zatrudniania osób niepełnosprawnych",

- program „Trener Pracy” - wspieranie osób niepełnosprawnych na otwartym rynku pracy.

Można także wymienić realizowane oferty programowe o charakterze bardziej ogólnym. Wśród nich na uwagę zasługuje „Program wsparcia inicjatyw na rzecz środowiska osób niepełnosprawnych” czy też „Program wyrównywania różnic między regionami II”.

Pomoc finansowa $\mathrm{w}$ ramach działalności PFRON jest przeznaczana przede wszystkim na:

- utrzymywanie miejsc pracy osób niepełnosprawnych,

- dofinansowywanie zadań wynikających z rządowych i samorządowych programów na rzecz osób niepełnosprawnych,

- programy celowe służące rehabilitacji zawodowej, społecznej, leczniczej, nych,

- tworzenie i utrzymywanie poradnictwa zawodowego dla osób niepełnospraw-

- dofinansowywanie turnusów rehabilitacyjnych, sportu, kultury dla osób niepełnosprawnych, finansowanie warsztatów terapii zajęciowej,

- dotacje dla przedsiębiorców produkujących sprzęt dla niepełnosprawnych,

- refundowanie składek na ubezpieczenia społeczne dla niepełnosprawnych prowadzących działalność gospodarczą,

- rekompensowanie pracodawcom podwyższonych kosztów zatrudnienia niepełnosprawnych,

- opracowywanie materiałów szkoleniowych i informacyjnych,

- dofinansowywanie budowy i modernizacji obiektów rehabilitacyjnych,

- dofinansowywanie likwidacji barier architektonicznych, urbanistycznych, transportowych.

Realizacja zadań PFRON odbywa się przy współpracy z przedstawicielami samorządów terytorialnych.

Istotna rola w realizowaniu polityki społecznej wobec osób niepełnosprawnych przypada samorządowi terytorialnemu. Władze samorządowe na różnych szczeblach realizują zadania pomocowe wobec osób niepełnosprawnych. W przypadku gminy należą do nich:

- przyznawanie i wypłacanie zasiłków okresowych i celowych,

- opłacanie składek na ubezpieczenia emerytalne i rentowe za osoby opiekujące się niepełnosprawnymi,

- prowadzenie i zapewnienie miejsc w placówkach wsparcia dziennego,

— kierowanie do domu pomocy społecznej wraz z odpłatnością,

- utworzenie, utrzymywanie i prowadzenie ośrodka pomocy społecznej, 
- współpraca z powiatowym urzędem pracy w zakresie upowszechniania informacji o miejscach pracy, szkoleniach i poradnictwie zawodowym dla niepełnosprawnych,

— organizowanie i świadczenie usług opiekuńczych w miejscu zamieszkania osób niepełnosprawnych,

- prowadzenie i rozwijanie domów samopomocy.

Wśród najważniejszych zadań na szczeblu powiatowym warto wymienić:

- opracowywanie i realizację powiatowych strategii rozwiązywania problemów społecznych z uwzględnieniem osób niepełnosprawnych,

- prowadzenie mieszkań chronionych i powiatowych ośrodków wsparcia,

— prowadzenie i rozwój domów pomocy społecznej o zasięgu ponadgminnym.

$\mathrm{Na}$ szczeblu regionalnym za najważniejsze zadania przyjęto:

- opracowywanie i realizację strategii polityki obejmującej programy przeciwdziałania wykluczeniu społecznemu i wyrównywania szans osób niepełnosprawnych,

- wspieranie i promowanie nowych pomysłów w zakresie pomocy społecznej,

— organizowanie i prowadzenie wojewódzkich jednostek organizacyjnych pomocy społecznej.

Polityka społeczna państwa powinna dążyć do poprawy sytuacji materialnej i prawnej niepełnosprawnych. Jej celem powinno być także dążenie do równouprawnienia osób niepełnosprawnych na rynku pracy, na rynku edukacyjnym, a także w dostępie do stanowisk zawodowych. Takie działania ułatwiają aktywizację zawodową niepełnosprawnych.

\section{Aktywność osób niepełnosprawnych na rynku pracy w Polsce}

Aktywność zawodowa stanowi istotne zagadnienie zarówno dla gospodarki danego państwa, jak i jego obywateli. Obecność osób niepełnosprawnych na rynku pracy odgrywa ważną rolę w ich rehabilitacji i integracji ze społeczeństwem ${ }^{8}$. Wpływa też na ich sytuację materialną. Wykonywanie pracy przez osoby niepełnosprawne oddziałuje na zrównoważony rozwój gospodarczy i społeczny kraju oraz na wykorzystanie ich potencjału wiedzy i umiejętności. Osoby bezrobotne są często postrzegane przez społeczeństwo jako bezwartościowe. Praca zapobiega zjawisku wykluczenia i marginalizacji osób niepełnosprawnych ${ }^{9}$.

Z punktu widzenia idei wyrównywania szans osób niepełnosprawnych jako podstawowego elementu polityki społecznej wobec niepełnosprawnych zasadnicze $i$ inspirujące znaczenie mają Standardowe zasady wyrównywania szans osób z niepełnosprawnościami.

8 A.I. Brzezińska et al., Aktywność osób z ograniczeniem sprawności na rynku pracy: czynniki wspomagajace i czynniki ryzyka, Warszawa 2008, s. 9.

9 R. Ossowski, Jakość życia - efektywne petnienie ról rodzinnych i zawodowych, [w:] Człowiek niepetnosprawny. Rodzina i praca, red. M. Kościelska, B. Aouil, Bydgoszcz 2004, s. 32. 
Gospodarstwo domowe jest podmiotem gospodarczym pełniącym wiele funkcji. Szczególnego znaczenia w odniesieniu do podmiotów tworzonych przez osoby o niepełnej sprawności nabiera funkcja opiekuńczo-zabezpieczająca ${ }^{10}$. Gospodarstwo domowe to jednocześnie podmiot, który w systemie gospodarki narodowej jest jednym $\mathrm{z}$ najmniejszych, najliczniej występujących i wyróżnia się spośród innych elementów systemu pewnymi istotnymi cechami. Głównym celem istnienia i funkcjonowania gospodarstwa domowego jest zaspokajanie potrzeb jego członków - zarówno indywidualnych, jak i wspólnych. Do realizacji tego celu niezbędne jest osiąganie odpowiedniego poziomu dochodów.

Wybrane wskaźniki aktywności ekonomicznej osób niepełnosprawnych przedstawia tabela 1.

Tabela 1. Wybrane wskaźniki aktywności na rynku pracy dla osób niepełnosprawnych w Polsce według kryterium prawnego oraz ludności ogółem w 2015 roku (w \%)

\begin{tabular}{l|c|c}
\hline \multicolumn{1}{c|}{ Wskaźnik } & $\begin{array}{c}\text { Ludność } \\
\text { ogółem }\end{array}$ & $\begin{array}{c}\text { Osoby } \\
\text { niepełnosprawne }\end{array}$ \\
\hline Współczynnik aktywności zawodowej & 56,0 & 25,9 \\
\hline Wskaźnik zatrudnienia & 50,7 & 22,5 \\
\hline Stopa bezrobocia & 9,5 & 13,0 \\
\hline
\end{tabular}

Źródło: http://www.niepelnosprawni.gov.pl/p,80,rynek-pracy.

Dane zawarte w tabeli 1 wyraźnie wskazują zarówno na niski poziom aktywności zawodowej osób niepełnosprawnych, jak i wskaźnik zatrudnienia. Wysoki poziom możemy za to zauważyć w przypadku wskaźnika stopy bezrobocia. Dane te należy uznać za niepokojące. Aktywność zawodowa osób niepełnosprawnych w Polsce wykazuje niski poziom i jest ponad trzy razy niższa niż w przypadku osób sprawnych. Jest to szczególnie widoczne w przypadku osób w wieku produkcyjnym. Po roku 2004 na polskim rynku pracy pojawiło się zjawisko spadku stopy bezrobocia. Jest ono mniej korzystne w odniesieniu do populacji niepełnosprawnych.

W Polsce średnio tylko co piąta osoba niepełnosprawna pracowała, podczas gdy w krajach starej Unii co druga osoba niepełnosprawna podejmuje zatrudnienie ${ }^{11}$. W 2008 roku wśród ogółu niepełnosprawnych jedynie 13,7\% uznano za pracujących. Aktywność zawodowa osób niepełnosprawnych w wieku produkcyjnym jest większa i wyniosła w 2008 roku 23,9\%. Ten poziom jest jednak zdecydowanie niższy w porównaniu z aktywnością osób sprawnych, który wyniósł w analogicznym roku 74,7\%. Wskaźnik stopy bezrobocia także jest niższy w przypadku osób sprawnych. W krajach starej UE odsetek osób niepełnosprawnych wśród pracujących wynosił $20 \%$.

10 L. Frąckiewicz, S. Waszczak, Polityka ludnościowa i rodzinna. Materiały do studiowania, Katowice 1997, s. 25-28.

11 A. Barczyński, R. Radecki, Raport z badań. Identyfikacja przyczyn niskiej aktywności zawodowej osób niepetnosprawnych, Warszawa 2008, s. 40. 
W świetle powyższego zestawienia wyraźnie widać ograniczoną skuteczność polityki społecznej państwa i jej mechanizmów aktywizacji zawodowej ${ }^{12}$.

Konsekwencje niepełnosprawności powodują, że osoby niepełnosprawne mogą mieć dodatkowe potrzeby, których zaspokojenie może stanowić źródło powodzenia ich aktywizacji zawodowej. Katalog tych dodatkowych potrzeb jest pochodną rodzaju niepełnosprawności oraz jej stopnia.

Potrzeby te można ująć następująco ${ }^{13}$ :

- na etapie wyboru zawodu: szczegółowa ocena zdolności do pracy dla ustalenia realnych możliwości zawodowych osoby niepełnosprawnej oraz poradnictwo zawodowe umożliwiające wybór kierunku i rodzaju szkolenia lub kształcenia zawodowego,

- na etapie przygotowania do pracy: pomoc w dostępie do odpowiedniej placówki edukacyjnej, wsparcie i pomoc w trakcie szkolenia lub kształcenia, dostosowanie metod i narzędzi procesu dydaktycznego,

- na etapie zatrudnienia: wyszukanie zainteresowanego pracodawcy dysponującego odpowiednim stanowiskiem pracy, dobór stanowiska pracy i zakresu zadań do możliwości i kwalifikacji zawodowych niepełnosprawnego, przystosowanie stanowiska pracy, stworzenie przyjaznych warunków pracy zapobiegających pogłębieniu się niepełnosprawności,

- na etapie adaptacji zawodowej w zakładzie pracy: zapoznanie niepełnosprawnego pracownika $\mathrm{z}$ fizycznym i społecznym środowiskiem pracy, z zadaniami zawodowymi i ewentualne dodatkowe przeszkolenie, wsparcie i pomoc w początkowym okresie zatrudnienia, monitorowanie zatrudnienia do momentu stabilizacji zawodowej niepełnosprawnego pracownika.

Poddając analizie przyczyny niskiej aktywności zawodowej niepełnosprawnych, należy wziąć pod uwagę kilka czynników. Składają się na nie elementy otoczenia zewnętrznego samej osoby niepełnosprawnej oraz decyzje i postawy pracodawcy.

Elementy otoczenia zewnętrznego stanowiące potencjalne przyczyny niskiej aktywności zawodowej niepełnosprawnych można podzielić na cztery grupy związane z funkcjonowaniem systemu rehabilitacji zawodowej, barierami wobec osób niepełnosprawnych, warunkami charakteryzującymi rynek pracy i otoczeniem prawnym. Bariery bezpośrednio związane z osobą niepełnosprawną mają charakter barier funkcjonalnych (urbanistyczne, transportowe, w komunikowaniu, techniczne i architektoniczne), wpływających na poziom rozwoju osoby niepełnosprawnej (w dostępie do informacji i edukacji), psychospołecznych (segregacja i izolacja społeczna osoby niepełnosprawnej) oraz finansowych z uwzględnieniem możliwości państwa w tym zakresie. Ograniczenia wynikające $z$ otoczenia zewnętrznego, a będące pochodną zasad funkcjonowania systemu rehabilitacji, to brak stabilności zasad funkcjonowania systemu, złożone procedury oraz zróżnicowane źródła wspierania finansowego. Elementy warunków funkcjonowania

12 A. Barczyński, Aktywność zawodowa niepełnosprawnych, „Praca i Rehabilitacja Niepełnosprawnych” 2005, nr 10/90, s. 12.

13 T. Majewski, Rodzaj niepelnosprawności a potrzeby osób niepetnosprawnych $w$ zakresie aktywizacji zawodowej, [w:] Materiały konferencyjne: Potrzeby osób niepetnosprawnych w zakresie aktywizacji zawodowej - konferencja KIG-R, Warszawa, 30 maja 2007, s. 23. 
rynku pracy mające wpływ na niską aktywność zawodową niepełnosprawnych to: poziom usług świadczonych osobom niepełnosprawnym z uwzględnieniem poradnictwa zawodowego, pośrednictwo pracy i problem dodatkowych szkoleń, jak również wysoki poziom bezrobocia, brak ofert pracy dla osób niepełnosprawnych i jednocześnie ich konkurencyjność.

Wśród potencjalnych czynników związanych z pracą, które dotyczą osoby niepełnosprawnej, można wyodrębnić jej dodatkowe potrzeby (rehabilitacja lecznicza, opieka lekarska, usługi opiekuńcze), cechy psychiczne (np. niższa koncentracja, stany zniecierpliwienia i niepokoju), ograniczenia wynikające z niepełnosprawności (warunków, miejsca, rodzaju i czasu pracy), przeciwwskazania (stan zdrowia, rodzaj i stopień niepełnosprawności, wiek), profil psychologiczny (zaniżone oczekiwania, niższe umiejętności w kontaktach, niska samoocena, apatia, brak motywacji) i niższą produktywność (słabe przygotowanie zawodowe wynikające z niższych kwalifikacji lub braku możliwości przekwalifikowania, niższa wydajność jako pochodna niższej sprawności intelektualnej lub fizycznej, krótszy czas pracy jako pochodna częstszej absencji chorobowej i ustawowych uprawnień, niższa jakość pracy oraz niższa mobilność).

Na decyzje i postawy pracodawcy zasadniczy wpływ mogą mieć dodatkowe obowiązki wynikające z zatrudnienia osoby niepełnosprawnej, konieczność ponoszenia podwyższonych kosztów funkcjonowania firmy oraz funkcjonujące uprzedzenia i stereotypy. Istotny element stanowi zagrożenie podwyższonymi kosztami ${ }^{14}, \mathrm{z}$ rozróżnieniem kosztów o wymiarze ekonomicznym (konsekwencja niższej produktywności osoby niepełnosprawnej, koszty dodatkowych braków jakościowych, opłaty dodatkowego personelu, likwidacja barier funkcjonalnych oraz potencjalny brak ciągłości zatrudnienia) i kosztów o wymiarze społecznym (konsekwencja niższej mobilności, niekorzystny klimat medialny, opinie o jakości produktów i usług wykonywanych przez niepełnosprawnych). Katalog przyczyn wynikających z postawy pracodawcy uzupełniają: dodatkowe obowiązki wynikające $\mathrm{z}$ rozbudowanej sprawozdawczości i rozliczeń oraz uprzedzenia i stereotypy w postaci niekorzystnych opinii o jakości pracy osób niepełnosprawnych oraz nieznajomość przepisów regulujących kwestie zatrudniania niepełnosprawnych.

Przyczyny związane ze środowiskiem pracy są pochodną konieczności dokonania ewentualnych zmian i adaptacji, jakich wymaga w związku z zatrudnieniem osoby niepełnosprawnej infrastruktura techniczna firmy, oraz postaw przełożonych i współpracowników wobec pracującej osoby niepełnosprawnej. Oprócz wymienionych wcześniej barier funkcjonalnych należy wymienić konieczność dokonania zmian o charakterze techniczno-organizacyjnym (zapewnienie opieki rehabilitacyjnej i medycznej, zmiany technologiczne i organizacji pracy). Natomiast pośród przyczyn związanych z postawami współpracowników należy wskazać uprzedzenia i stereotypy funkcjonujące w otoczeniu, utrwalane opinie o niskiej jakości pracy niepełnosprawnych i ich przywilejach oraz zagrożeniu konkurencyjnością zatrudnianych niepełnosprawnych.

14 A. Barczyński, Metoda obliczania kosztów związanych z rehabilitacją i zatrudnianiem osób niepełnosprawnych w zakładzie pracy chronionej - MOKON-02, KIG-R: Warszawa, maj 2004, z. 27, s. 33-34. 
Powyższy zbiór potencjalnych przyczyn niższej aktywności zawodowej osób niepełnosprawnych unaocznia złożoność problematyki zarówno na etapie rozpoznania, jak i poszukiwania oraz stosowania skutecznych narzędzi uaktywnienia zawodowego niepełnosprawnych. Wskazuje też na potrzebę systemowego poszukiwania rozwiązań.

Jedną z barier aktywności zawodowej osób niepełnosprawnych jest również sytuacja związana z otrzymywaniem różnego rodzaju świadczeń. Jest to czynnik, który działa demobilizująco na osoby niepełnosprawne oraz ich gospodarstwa domowe.

\section{Dochody i wydatki gospodarstw domowych z osobami niepełnosprawnymi}

Aktywność zawodowa osób niepełnosprawnych wpływa w istotny sposób na ich dochody i wydatki, które stanowią istotny wskaźnik opisujący sytuację materialną i budżetową gospodarstw domowych. W literaturze ekonomicznej funkcjonuje wiele definicji dochodu, zarówno w ujęciu mikro-, jak i makroekonomicznym. Dochód stanowi miarę finansową pożytków czerpanych z różnych źródeł. Uważa się za niego wszelkie przychody po odliczeniu kosztów ich uzyskania oraz po odliczeniu składek na ubezpieczenie emerytalne i rentowe oraz na ubezpieczenie chorobowe, określonych w przepisach o systemie ubezpieczeń społecznych, chyba że zostały już zaliczone do kosztów uzyskania przychodu ${ }^{15}$. Według Franka A. Cowella dochód to przyrost rozporządzalnych przez daną osobę zasobów w danym okresie ${ }^{16}$. Z kolei Anthony B. Atkinson traktuje dochód jako kwotę, którą dana osoba może wydać bez naruszania jej majątku ${ }^{17}$. Znaczący wkład w definiowanie dochodu wniósł Eurostat. Opracował on koncepcję dochodu do dyspozycji, który pochodzi z:

- dochodów od aktywności,

- dochodów od własności,

- uzyskiwanych transferów.

Od sumy tej należy odjąć podatki bezpośrednie, inne opłaty oraz dobrowolne płatności transferowe.

Zasadniczymi składnikami dochodów gospodarstw domowych, uwzględnianymi w badaniach z zakresu statystyki społecznej, są:

- wynagrodzenie za pracę najemną,

- przychody z prowadzonej działalności gospodarczej,

- przychody z własności,

- transfery pieniężne.

Zróżnicowanie źródeł dochodów gospodarstw domowych prowadzących działalność rolniczą współtworzonych przez osoby niepełnosprawne przedstawia tabela 2.

\footnotetext{
15 www.bip.krakow.pl.

16 F.A. Cowell, Measuring Inequality, Hemel Hempstead 1995, s. 5.

17 A.B. Atkinson, The Economics of Inequality, Oxford 1983, s. 33.
} 
Tabela 2. Źródła dochodów gospodarstw domowych prowadzących działalność rolniczą, współtworzonych przez osoby niepełnosprawne w Polsce w 2011 roku

\begin{tabular}{l|c}
\hline \multicolumn{1}{c|}{ Źródła dochodów } & Wartość w \% \\
\hline Dochody z tytułu oszczędności & 0,2 \\
\hline Dochody z tytułu wynajmu, dzierżawy & 0,3 \\
\hline Praca za granicą & 0,3 \\
\hline Praca sezonowa & 1,3 \\
\hline Źródła niezarobkowe & 12,7 \\
\hline Emerytura & 1 \\
\hline Renta & 68,1 \\
\hline Dochody z pracy w rolnictwie & 14 \\
\hline Dochody z pracy poza rolnictwem & 17 \\
\hline Inne źródła & 2,9 \\
\hline
\end{tabular}

Źródło: Opracowanie własne na podstawie http://ageconsearch.umn.edu/bitstream/205187/2/16-4-Siedlecka.pdf.

Analiza danych zawartych w tabeli 2 wyraźnie wskazuje na duże zróżnicowanie w poziomie dochodów. W powyższym zestawieniu pozycję dominującą zajmują dochody osiągane z tytułu świadczeń socjalnych (renty) w przypadku gospodarstw domowych prowadzących działalność rolniczą, współtworzonych przez osoby niepełnosprawne. Natomiast stosunkowo niski odsetek przypada na dochody osiągane $\mathrm{z}$ tytułu pracy $\mathrm{w}$ rolnictwie. Warty odnotowania jest fakt uzyskiwania stosunkowo wysokich dochodów z działalności pozarolniczej.

Jednym z instrumentów pozwalających gospodarstwom domowym współtworzonym przez osoby niepełnosprawne na osiąganie oczekiwanego poziomu dochodów są działania związane $\mathrm{z}$ dywersyfikacją dochodów. W omawianej grupie niepełnosprawnych może to następować przez podejmowanie dodatkowego zatrudnienia.

Struktura źródeł dochodów rozporządzalnych gospodarstw z wszystkimi osobami sprawnymi różni się od struktury dochodów gospodarstw z osobami niepełnosprawnymi. W pierwszym przypadku dominują źródła pochodzące z pracy najemnej, w drugim zaś - świadczenia $\mathrm{z}$ ubezpieczeń społecznych. W obu typach gospodarstw dochody z pracy i z ubezpieczeń stanowią 75\% całego dochodu rozporządzalnego.

Korzystna sytuacja materialna gospodarstw $\mathrm{z}$ osobami niepełnosprawnymi jest kreowana przez dochody pochodzące z pracy najemnej i pracy na własny rachunek. Niekorzystna sytuacja materialna jest wynikiem pochodzenia dochodu z różnych świadczeń, które są mniej dochodowe niż praca. Przeciętny miesięczny dochód rozporządzalny i wydatki na osobę w gospodarstwach domowych $\mathrm{z}$ osobami i bez osób niepełnosprawnych w latach 2013-2014 przedstawia rycina 1.

Poniżej przeciętnej krajowej — o 15,6\% (w 2013 roku o 16,7\%) — kształtował się średni miesięczny dochód rozporządzalny na osobę w gospodarstwach domowych, w których mieszkała osoba niepełnosprawna. Także wydatki gospodarstw domowych z osobami 
niepełnosprawnymi były o 15\% niższe od przeciętnych miesięcznych wydatków w gospodarstwach ogółem (w 2013 roku o 14,5\%).

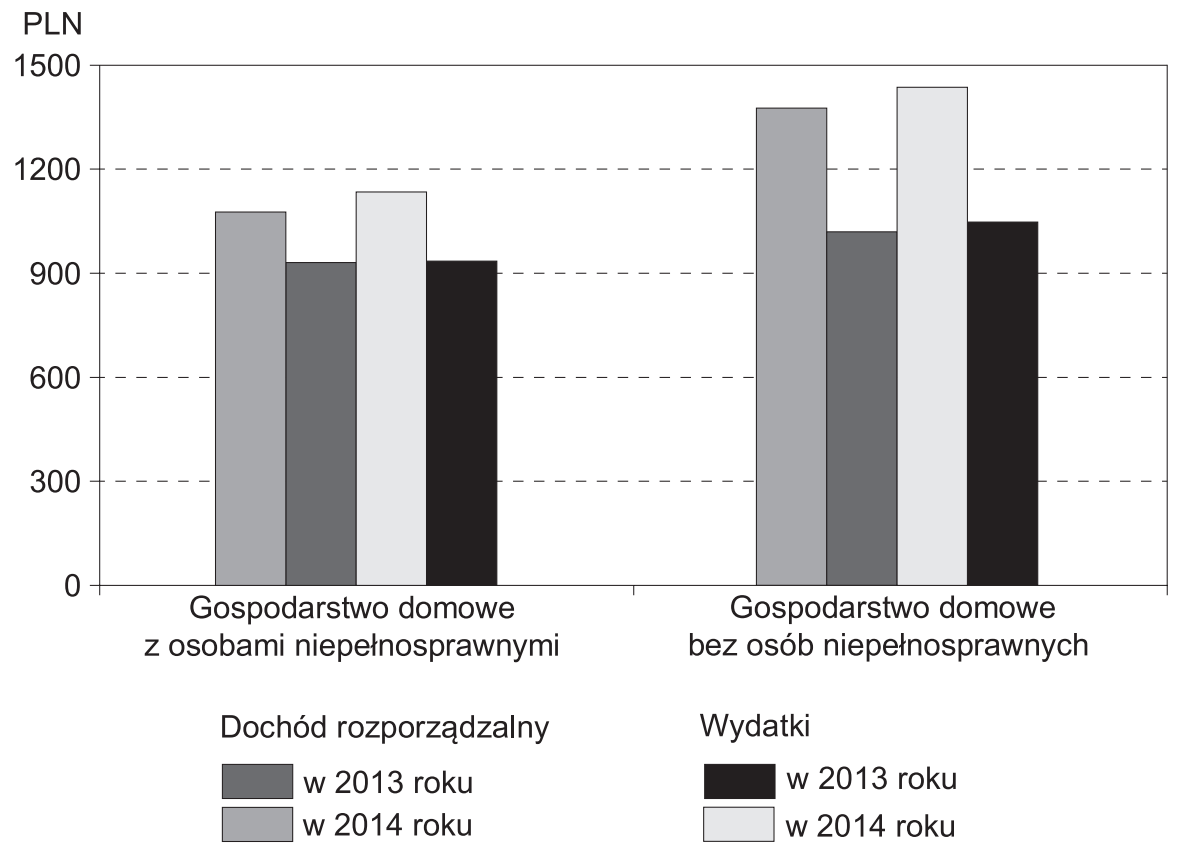

Rycina 1. Przeciętny miesięczny dochód rozporządzalny i wydatki na osobę w gospodarstwach domowych z osobami i bez osób niepełnosprawnych w latach 2013-2014

Źródło: Opracowanie własne na podstawie danych GUS.

Struktura źródeł dochodu rozporządzalnego jest uzależniona od obecności osoby niepełnosprawnej w gospodarstwie oraz jest odmienna dla osób sprawnych i niepełnosprawnych. Poziom osiąganych dochodów zależy też od wieku, wykształcenia oraz stopnia niepełnosprawności.

$\mathrm{Na}$ trudną sytuację materialną rodzin współtworzonych przez osoby niepełnosprawne wskazują wyniki badań kwestionariuszowych przeprowadzonych w 2010 roku wśród 800 niepełnosprawnych mieszkańców województwa lubelskiego. Większość respondentów (70,6\%) dysponowała dochodami niepozwalającymi na zaspokojenie podstawowych potrzeb. Co trzeci ankietowany ocenił sytuację materialną swojej rodziny jako złą (31,4\%), co drugi zaś jako przeciętną (55,7\%). Tak niekorzystna sytuacja materialna badanych była konsekwencją tego, że większość z nich była bezrobotna, a głównym źródłem ich utrzymania były renty ${ }^{18}$.

18 D. Tomczyszyn, Aktywność zawodowa osób z niepetnosprawnościa w opiniach osób niepetnosprawnych pochodzących $z$ terenów wiejskich województwa lubelskiego, [w:] Determinanty aktywności zawodowej osób niepetnosprawnych zamieszkatych na obszarach wiejskich $w$ województwie lubelskim. Raport $z$ badań, Biała Podlaska 2011, s. 37. 
Wydatki gospodarstw domowych stanowią oprócz dochodów istotny element analizy budżetów gospodarstw domowych. Można zauważyć, że przeciętny poziom wydatków gospodarstw z osobami niepełnosprawnymi jest znacząco niższy niż w gospodarstwach z wszystkimi osobami sprawnymi.

\section{Podsumowanie}

Niski poziom aktywności zawodowej osób niepełnosprawnych w Polsce, a także niezadowalający poziom ich dochodów i wydatków powinny stanowić istotne czynniki motywujące do prowadzenia działań w zakresie polityki społecznej. W pierwszej kolejności należy tutaj podkreślić podejmowanie działań legislacyjnych. Jednak prowadzenie polityki społecznej wobec osób niepełnosprawnych wymaga systematycznego monitorowania sytuacji i diagnozowania wpływu wprowadzanych zmian na ich aktywność zawodową. Pomocne mogą się okazać rezultaty badań przeprowadzanych przez ośrodki naukowo-badawcze oraz instytucje i organizacje zawodowo zajmujące się problematyką osób niepełnosprawnych.

Brak skutecznej polityki społecznej wobec osób niepełnosprawnych będzie miał negatywne skutki zarówno dla samych niepełnosprawnych, jak i całej gospodarki w długim okresie. W przypadku osób niepełnosprawnych będzie rosło poczucie frustracji, zniechęcenia, wykluczenia i marginalizacji społecznej. Natomiast najważniejszą stratą dla gospodarki będzie niewykorzystany potencjał twórczy tkwiący w wielu osobach niepełnosprawnych, który mógłby przyczynić się do powiększania PKB. Pracujące osoby niepełnosprawne mniej obciążałyby budżet państwa, natomiast dostarczałyby dochodów pochodzących z podatków.

\section{Bibliografia}

Atkinson A.B., The Economics of Inequality, Oxford 1983.

Balcerzak-Paradowska B., Sytuacja bytowa gospodarstw domowych osób niepetnosprawnych, [w:] Sytuacja osób niepetnosprawnych w Polsce, red. B. Balcerzak-Paradowska, Warszawa 2002.

Barczyński A., Aktywność zawodowa niepetnosprawnych, „Praca i Rehabilitacja Niepełnosprawnych” 2005, nr 10/90.

Barczyński A., Metoda obliczania kosztów związanych z rehabilitacją i zatrudnianiem osób niepetnosprawnych w zakładzie pracy chronionej - MOKON-02, KIG-R, Warszawa, maj 2004, z. 27.

Barczyński A., Radecki R., Raport z badań. Identyfikacja przyczyn niskiej aktywności zawodowej osób niepetnosprawnych, Warszawa 2008.

Barnes C., Mercer G., Niepetnosprawność, Sic!, przeł. P. Morawski, Warszawa 2008.

Brzezińska A.I. et al., Aktywność osób z ograniczeniem sprawności na rynku pracy: czynniki wspomagające i czynniki ryzyka, Warszawa 2008.

Cowell F.A., Measuring Inequality, Harvester Wheatsheaf, Hemel Hempstead 1995.

Frąckiewicz L., Waszczak S., Polityka ludnościowa i rodzinna. Materiały do studiowania, Katowice 1997. 
Majewski T., Rodzaj niepełnosprawności a potrzeby osób niepetnosprawnych w zakresie aktywizacji zawodowej, [w:] Materialy konferencyjne: Potrzeby osób niepełnosprawnych w zakresie aktywizacji zawodowej - konferencja KIG-R, Warszawa 30 maja 2007.

Majka J., Katolicka nauka społeczna, Ośrodek Dokumentacji i Studiów Społecznych, Warszawa 1988.

Ossowski R., Jakość życia - efektywne pełnienie ról rodzinnych i zawodowych, [w:] Człowiek niepełnosprawny. Rodzina i praca, red. M. Kościelska, B. Aouil, Bydgoszcz 2004.

Platon, Państwo, przeł. W. Witwicki, Kęty 1997, ks. 5, par. 9-10.

Tomczyszyn D., Aktywność zawodowa osób z niepetnosprawnościq w opiniach osób niepetnosprawnych pochodzacych z terenów wiejskich województwa lubelskiego, [w:] Determinanty aktywności zawodowej osób niepełnosprawnych zamieszkałych na obszarach wiejskich w województwie lubelskim. Raport $z$ badań, Państwowa Szkoła Wyższa im. Papieża Jana Pawła II w Białej Podlaskiej, Biała Podlaska 2011.

Ulman P., Sytuacja ekonomiczna osób niepetnosprawnych i ich gospodarstw domowych $w$ Polsce, Wyd. UEK Kraków, Kraków 2011.

\section{Źródła internetowe}

http://ageconsearch.umn.edu/bitstream/205187/2/16-4-Siedlecka.pdf.

www.bip.krakow.pl.

http://www.cbe.ahe.lodz.pl/archiwalna_cbrk/sytuacja\%20osob.pdf.

http://www.niepelnosprawni.gov.pl/p,80,rynek-pracy.

http://www.niepelnosprawni.pl/files/www.niepelnosprawni.pl/public/rozne_pliki/fakty_i_mity_2009.pdf.

http://www.pfron.org.pl/ftp/dokumenty/EQUAL/Kluczowa_rola_gminy/Identyfikacja_przyczyn_niskiej_

aktywnosci_zawodowej_ON_raport_z_badan.pdf.

http://stat.gov.pl/.

http://stat.gov.pl/spisy-powszechne/nsp-2011/.

http://www.watchdogpfron.pl/wp-content/uploads/2014/03/Krynska-Sytuacja-ON.pdf.

\section{Social policy towards people with disabilities in Poland}

Keywords: social policy, disability, person with disability, occupational activity.

\section{Summary}

The problem of disability is an element of social and economic policy of the state. In Poland, disability affects every tenth person and is present in every fourth household. The wide range of actions is aimed at equality and improvement of the situation of people with disabilities through elimination of architectural, legal or mental barriers.

The aim of the publication was to present selected elements of social policy towards the disabled people in Poland, by an indication of the task purpose fund responsible for this area (PFRON) and the tasks of local authorities in this matter.

The publication is based on the available literature, statistical data and netography. The article presents briefly the nature and genesis of the concept of disability. It presents as well characteristics of the scale of disability in Poland and discusses the evolution of approaches to persons with disabilities in time. 